\title{
90 years of insulin therapy - analysis of its success and failure
}

\author{
Viktor Rosival* \\ SYNLAB Department of laboratory Medicine, Dérer’s Hospital, Limbová 5, SK-833 05 Bratislava, Slovakia
}

Insulin therapy has successfully solved all problems of hyperglycemic hyperosmolar non-ketotic state, and tha result of insulin treatment is also that life-threatening hyperglycemic hyperosmolar non-ketotic state with coma occurs today very seldom, only in diabetic patients who did not follow recommendations for insulin therapy. In diabetic ketoacidotic coma, insulin is without effect however, correctly applied alkalizing therapy is life-saving.

One hundred years ago at the beginning of the $20^{\text {th }}$ century, two diseases had an almost 100\% lethality: pernicious anaemia and diabetic ketoacidosis. Between the two World wars, substantial progress in their pathogenesis has been honoured with Nobel prizes.

Today, at the beginning of the $21^{\text {th }}$ century, nobody remembers lethal outcome in a patient, with pernicious anaemia, whereas between 1990 and 2010 yearly 2000-3000 patients dies in USA in "hyperglycemic crises", despite the availability of insulin therapy [1].

To explain and understand this surprisingly unfavourable result it is necessary to call attention that diabetic ketoacidosis (DKA) today is not the same as DKA 90 years ago.

Lethal coma in DKA has been first reported 1874 by Kussmaul [2], but already in 1881 has Dreschfeld [3] reported lethal coma without acetoacetic acid in diabetes mellitus. Progress in biochemistry has made possible to measure blood-pH and according to Rolly [4] in 1913, out of 11 comatose diabetic patients only 3 had acidotic blood. Rolly has emphasized that in the majority of these patients an "acidctic coma" was excluded. However, this non-acidotic coma (coma in hyperglycemic hyperosmolar non-ketotic state, HHNs) has been generally accepted only after the case history of Sament and Schwartz in 1957 [5]. It is difficult to understand why HHNS has been acknowledged only 76 years after its first description by Dreschfeld!!! Thus, when in 1922 insulin was introduced in the therapy of diabetes, the reality was that the majority of comatose patients ware in HHNS, not in DKA, and the decrease of lethal outcome in comatose patients was the consequence of insulin treatment of HHNS, and. not of DKA.

With the acceptance of HHNS emerged a new problem: after the discovery of insulin, its absence has been considered as the cause of DKA; however, the existence of the "new" HHNS must be also in some way linked to insulin deficiency. A "very simple" solution has been found: decreased concentration of plasmatic insulin is the cause of HHNS, its absolute deficiency is the cause of DKA. But successively appeared reports which casted doubt on the role of insulin in the development of DKA: the existence of euglycemic DKA [6] and even DKA in hypoglycaemia [7] is difficult to explain as consequence of insulin deficiency.

The Nobel Prize 1977 to Rosalyn S. Yalow, for development of new methods of biochemical analysis that make it, possible to measure insulin concentration in human plasma has definitively made clear that insulin does not participate in the pathogenesis of DKA. Already in 1981 has been published the monograph "Diabetic coma: katoacidotic and hyperosmclar" [8]. There, on p 67 is the Figure 6.3 with names of 12 authors who have reported sufficient amounts of plasmatic insulin in patients with DKA. On the other hand, absolute deficiency of plasmatic insulin has been reported in patients with coma in HHNS [9] and also in diabetic patients without subjective complaints [10]. Thus, DKA is insulin-independent, whereas in HHNS the life-threatening dehydration caused by hyperglycemia with glycosuric polyuria is successfully treated with insulin.

The key problem of DKA is the lethal coma, without connection to insulin. According to three papers [11-13], the immediate cause of coma in DKA is very low blood-pH (=very high concentration of hydrogen ions $\mathrm{H}^{+}$), regardless what are the accompanying anions: the glycolytic enzyme phosphofructokinase is $\mathrm{pH}$-dependent, as its activity is decreasing; with decreasing $\mathrm{pH}$ [14]. Therefore, with decreasing blood-pH is decreasing also the utilisation of glucose in brain cells [15]. Already in the 19th century have been reported increased amounts of acetoacetic and beta-hydroxybutyric acids in diabetic patients and this is also the origin of the name "ketoacidosis". In 1924, Starr and Fitz [16] have measured the concentration of "acetone bodies" and the total acidity in urine and blood of patients with DKA: total acidity was greater than the acidity of "ketone bodies". Their conclusion was that there are also "unidentified acids" in patients with DKA and they have asked on their p 100 "whether such unidentified acids may have played part in producing the clinical picture of diabetic coma". Progress in methods of biochemical analysis has made possible to identify successively 34 of such "unidentified acids" [17]. The mutual relation of these together 36 acids is variable, including severe acidosis without acetoacetic and beta-hydroxybutyric acids, e g [18]. Another example for the presence of other acids than traditional "acetone bodies": high level of lactic acid in patients with DKA [19].

If insulin therapy has no positive effect in life-threatening acidosis, remains the question, what could then be the effective treatment? If the low blood-pH is in reality the cause of decreased level of consciousness, the increase of the low blood-pH after infusions of alkalizing solutions (such as sodium bicarbonate) should be followed by return to normal level of consciousness. As an example of zero lethality of coma in DKA after treatment with sodium bicarbonate can serve the paper of Umpierrez et al. [20]. It is necessary to emphasize that the alkalizing

Correspondence to: Viktor Rosival, SYNLAB Department of laboratory Medicine, Dérer's Hospital, Limbová 5, SK-833 05 Bratislava, Slovakia, E-mail: rosivalv@hotmail.com

Received: June 25, 2017; Accepted: July 22, 2017; Published: July 24, 2017 
therapy must begin as soon as possible before the damage of brain has reached the irreversible stage.

\section{References}

1. Gregg EW, Li Y, Wang J, Burrows NR, Ali MK, et al. (2014) Changes in diabetes-related complications in the United States, 1990-2010. N Engl J Med 370: 1514-1523. [Crossref]

2. Kussmaul A (1874) Zur Lehre vom Diabetes mellitus. Dtsch Arch Klin Med 14: 1-47.

3. Dreschfeld J (1881) Reports of societies: Manchester medical society, Wednesday, October 5th, 1881. Brit Med J 2: 710 .

4. Rolly F (1913) Das Wesen und die Behandlung des Coma diabeticum. Med Klinik 15: 568-572.

5. SAMENT S, SCHWARTZ MB (1957) Severe diabetic stupor without ketosis. $S A f$ Med J 31: 893-894. [Crossref]

6. Munro JF, Campbell IW, McCuish AC, Duncan LJ (1973) Euglycaemic diabetic ketoacidosis. Br Med J 2: 578-580. [Crossref]

7. Malcon ML, Klos SE, Gennis VM, Goodwin JS (1992) Frequent Hypoglycemic Episodes in the Treatment of Patients with Diabetic Ketoacidosis. Arch Intern Med 152: 2472-2477. [Crossref]

8. Schade NS, Eaton RP, Alberti KGMM (1981) Diabetic coma: ketoacidotic and hyperosmolar. Albuquerque: University of New Mexico Press.

9. Vinik A, Seftel LT, Joffe BD (1975) Metabolic findings ln hyperosmolar nonketotic diabetic stupor. Lancet 7: 45-46.

10. Matsuyama T, Hoffman WH, Dunbar JC, Foà NL, Foà PP (1975) Glucose, insulin, pancreatic glucagon and glucagon-like immunoreactive materials in the plasma of normal and diabetic children. Effect of the initial insulin treatment. Horm Metab Res 7: 452-456. [Crossref]
11. Rosival V (1987) The influence of blood hydrogen ion concentration on the level of consciousness in diabetic ketoacidosis. Ann Clin Res 19: 23-25. [Crossref]

12. Edge JA1, Roy Y, Bergomi A, Murphy NP, Ford-Adams ME, et al. (2006) Conscious level in children with diabetic ketoacidosis is related to severity of acidosis and not to blood glucose concentration. Pediatr Diabetes 7: 11-15. [Crossref]

13. Nyenwe EA, Razavi LN, Kitabchi AE, Khan AN, Wan JY (2010) Acidosis: The prime Determinant of Depressed Sensorium in Diabetic Ketoacidosis. Diabetes Care 33: 1837-1839. [Crossref]

14. Trivedi B, Danforth WH (1966) Effect of $\mathrm{pH}$ on the kinetics of frog muscle phosphofructokinase. J Biol Chem 241: 4110-4112. [Crossref]

15. Van Nimnen D, Weyne J, Demeester G et al. (1984) Local cerebral glucose utilisation in systemic acidosis. Am J Physiol 247: R639-R645. [Crossref]

16. Starr P, Fitz R (1924) The Excretion of Organic Acids in the Urine of Patients with Diabetes Mellitus. Arch lntern Med 33: 97-108.

17. Niwa T (1995) Mass spectrometry in diabetes mellitus. Clin Chim Acta 141-2: 193-220. [Crossref]

18. Vernon DD, Postellon DC (1986) Nonketotic hyperosmolal diabetic coma in a child: management with low-dose insulin infusion and intracranial pressure monitoring. Pediatrics 77: 770-772. [Crossref]

19. Cox K1, Cocchi MN, Salciccioli JD, Carney E, Howell M, et al. (2012) Prevalence and significance of lactic acidosis in diabetic ketoacidosis. J Crit Care 27: 132-137. [Crossref]

20. Umpierrez GE1, Kelly JP, Navarrete JE, Casals MM, Kitabchi AE (1997) Hyperglycemic crises in urban blacks. Arch Intern Med 157: 669-675. [Crossref]

Copyright: $(02017$ Rosival V. This is an open-access article distributed under the terms of the Creative Commons Attribution License, which permits unrestricted use, distribution, and reproduction in any medium, provided the original author and source are credited. 